DOI https://doi.org/10.30525/978-9934-26-038-4-18

\title{
JUSTIFICATION OF THE APPLICATION OF PHYSICAL THERAPY IN YOUTH WITH ARTERIAL HYPERTENSION
}

\author{
Ivanko O. H. \\ Doctorate of Philosophy in Medicine, \\ Professor at the Department of Propaedeutics of Children's Diseases, \\ Propaedeutics of Children's Diseases \\ Zaporizhzhia State Medical University
}

Tovma A. V.

Candidate of Medical Sciences, Assistant at the Department of Propaedeutics of Children's Diseases, Propaedeutics of Children's Diseases

Zaporizhzhia State Medical University

\section{Patsera M. V. \\ Candidate of Medical Sciences,} Associate Professor at the Department of Propaedeutics of Children's Diseases, Propaedeutics of Children's Diseases Zaporizhzhia State Medical University

\section{Skrypnykova Y.S.}

Assistant at the Department of Propaedeutics of Children's Diseases, Propaedeutics of Children's Diseases

Zaporizhzhia State Medical University

Zaporizhzhia, Ukraine

Over recent decades, a steady increase in arterial hypertension (AH) has been observed among the adult population of the world. It is known that this disease first occurs in adolescence. The prevalence of AH among school-age children varies from 2.4 to $14 \%$, and can reach $18 \%$ among adolescents [1, p. 27]. The factors of elevated blood pressure (BP) among young people are psycho-emotional and informational loads, irrational diet with excessive consumption of salt, sedentary lifestyle, smoking, hereditary predisposition, and others. [2, p. 53]. An important fact is that adolescents do not feel sick and almost do not seek medical assistance when their BP begins to rise. Therefore, the timely start of the diagnosis of $\mathrm{AH}$, treatment and prevention of cardiovascular complications is important [3, p. 48]. 
There are problems with the timing of the start of treatment for $\mathrm{AH}$ with drug therapy, when the disease is still developing, and it is still difficult to predict its course. Recommendations have been developed for physical therapy of AH based on physical dynamic aerobic exercises, which significantly reduce $\mathrm{BP}$ in young people. The problem of the possibility of predicting the results of treatment of $\mathrm{AH}$ in adolescents with exercise is insufficiently studied, and perhaps, in solving it, we could organize medical care for adolescents at the beginning of the manifestations of AH more effectively [4, p. 4].

The objective of this study was to define the effectiveness of physical therapy among young people aged 16-17 with $\mathrm{AH}$, taking into account the course of the disease and its long-term prognosis. In 2008-2018, on-site BP measurement was performed during preventive examinations in 1,700 firstyear students, from which follow-up groups were formed. Medical staff of pediatric and therapeutic departments of Zaporizhzhia State Medical University was involved in the procedure. Adolescents who had BP $\geq 120 / 80 \mathrm{~mm}$ $\mathrm{Hg}$ in two cases out of three were assigned to the group with a probable $\mathrm{AH}$ diagnosis. Subsequently, those individuals underwent daily BP monitoring (DBPM) using the Cardio Tens device (Meditech Ltd., Hungary), and their body mass index (BMI) and physical performance (PP) were measured using a bicycle ergometric submaximal test $\mathrm{PWC}_{170}$. Other tests were daily Holter electrocardiography monitoring, echocardiography, ultrasound examination of kidneys, adrenal glands, and thyroid gland and ophthalmoscopy of the fundus. The study group consisted of 87 adolescents who underwent all stages of diagnosis and were identified as suffering from AH. Other 42 adolescents, who were identified as normotensive during the examination, formed the comparison group.

We have developed a program of health preservation technology aimed at BP correction, body mass control, and PP increase, which included the organization of a gym using Progress VK-1061 exercise bicycles at the university under the supervision of a training instructor, and implemented it into the practice of our institution. Training sessions on exercise bicycles were conducted 2 times a week for 50 minutes over 7 months. During the training session on the exercise bicycle, the loads were selected by determining the individual «pulse value» of the session. BP was measured for medical control before training sessions, immediately after getting off the bicycle and after 5 minutes of rest [5, p. 3-5].

Among adolescents with $\mathrm{AH}$, the I-a subgroup of individuals (26 boys and 18 girls) who trained on exercise bicycles was identified. The I-b comparison subgroup, representative of BP, PP, and BMI indicators, consisted of 20 boys and 18 girls who did not train on exercise indicators, but carefully 
followed the recommendations to maintain a healthy lifestyle. The observation time was 14 months, which allowed to assess both the direct results of training, which lasted 7 months during the school year, and long-term ones, 7 months after its completion. During the training program on exercise bicycles, a decrease in systolic BP by $14-20 \mathrm{~mm} \mathrm{Hg}$ was observed in both boys and girls, according to the results of immediate measurements after the training on the exercise bicycle at the beginning of the recovery period, i.e. During the fifth minute of rest. Changes in diastolic BP were less significant, 2-8 $\mathrm{mm} \mathrm{Hg}$.

The results of our study showed that during the program, adolescents in the I-a subgroup have improved their PP. According to the $\mathrm{PWC}_{170}$ test, in boys who have fully completed the 7 months $\mathrm{AH}$ physical rehabilitation program, PP has increased from $12.2 \pm 1.8(\mathrm{kgm} / \mathrm{min})$ per $1 \mathrm{~kg}$ of body mass to $15.9 \pm 1.7(\mathrm{kgm} / \mathrm{min})$ per $1 \mathrm{~kg}$ of body mass $(\mathrm{p}<0.05)$. A similar trend of $\mathrm{PWC}_{170}$ indicators increase was observed among girls who trained: from $8.2 \pm 2.4(\mathrm{kgm} / \mathrm{min})$ per $1 \mathrm{~kg}$ of body mass to $13.16 \pm 1.6(\mathrm{kgm} / \mathrm{min})$ per $1 \mathrm{~kg}$ of body mass ( $\mathrm{p}<0.05)$. Comparative studies of the average daily BP conducted via DBPM after 7 months after the completion of the program found the preservation of positive changes in the health of both boys and girls. As for the I-b comparison subgroup, the observations in adolescents did not reveal significant dynamics of the average daily BP, according to DBPM data. Over 14 months, the indicators of systolic and diastolic BP have increased slightly in boys and girls of the I-b subgroup (from 2 to $5 \mathrm{~mm} \mathrm{Hg}$ ). It is important to note that according to echocardiography, an increase in the incidence of signs of LV myocardial remodeling has been observed in patients of the I-a subgroup during the observation period, from $13.6 \%$ at the beginning of the study to $36.1 \%$ at the end, and from $9.0 \%$ to $68.2 \%$ accordingly in the I-b comparison subgroup, mainly among boys. It should be emphasized that over the observation period, the PP and BMI indicators have not changed significantly in adolescents of the I-b subgroup. Additional observations of young people of group II, who were not involved in the physical rehabilitation program, allowed to identify the prognostically significant predictors of LVH development. The search for predictors was performed on the basis of ROC and logistic-regression analysis of comparisons of clinical, anthropometric, and hemodynamic indicators at the time of diagnosis of $\mathrm{AH}$ with subsequent disease development over 12 months. The risk of LVH development over the next 12 months could be predicted by detecting BMI $\geq 25 \mathrm{~kg} / \mathrm{m}^{2}$, average daily pulse pressure by DBPM $\geq 57 \mathrm{~mm} \mathrm{Hg}$, and left ventricle posterior wall thickness $\geq 0.8 \mathrm{~cm}$. 
Therefore, the application of health preservation technologies, while taking into account their potential and limitations, creates new prospects for the provision of medical care to adolescents with $\mathrm{AH}$ under the conditions of the physical therapy program implemented directly in the educational institution. With the high probability of developing LVH in the nearest future in adolescents with primary $\mathrm{AH}$, which limits the effectiveness of physical therapy, it is advisable to prescribe physical therapy in combination with antihypertensive drugs with their possible cancellation in the future provided sufficient physical activity while continuing physical therapy.

\section{References:}

1. Товма А.В. Удосконалення діагностики та прогнозування розвитку ремоделювання лівого шлуночка у підлітків 3 первинною артеріальною гіпертензією.: дис. ... канд. мед. наук: 14.01.10. Запоріжжя, 2020. 199 c.

2. Марушко Ю. В., Гищак Т. В. Артеріальна гіпертензія у дітей та підлітків. Здоров'я України. Тематичний номер «Педіатрія». 2019. № 1 (48), березень 2019. С. 53-58.

3. Товма А. В., Іванько О. Г., Пацера М. В. Визначення показань до фізичної реабілітації підлітків 3 первинною артеріальною гіпертензією з використанням клініко-математичного прогнозування. Міжнар. журн. педіатрії, акушерства та гінекології. 2019. Т. 13, № 3 : матеріали XIV з'їзду педіатрів України «Актуальні проблеми педіатрії» Київ : 8-10 жовтня 2019 р. С. 48-49.

4. Іванько О. Г., Товма А. В., Пацера М. В. Терапевтична тактика при проведенні профілактичних оглядів підлітків 16-17 років з артеріальною гіпертензією. Ліки - людині. Сучасні проблеми фармакотерапії і призначення лікарських засобів : матеріали III Міжнар. наук.-практ. конф. (Харків, 14-15 березня 2019 р.). Харків, 2019. Т. 2. С. 112-113.

5. Недельська Є.В. Саногенетичні ефекти занять на велотренажері у підлітків із первинною артеріальною гіпертензією: автореф. дис. ... канд. мед. наук: 14.01.10. Запоріжжя, 2016. 24 с. 